\title{
Аналіз міжнародного досвіду з організації системи державних закупівель озброєння та військової техніки
}

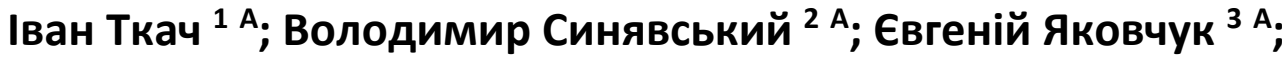 \\ Михайло Рудий 4 А; Володимир Корчицький 5 А; Роман Сергієнко 6 А \\ А Національний університет оборони України імені Івана Черняховського, пр-кт Повітрофлотський 28, м. Київ, 03049, Україна
}

Received: April 5, 2021 | Revised: April 27, 2021 | Accepted: April 30, 2021

DOI: $10.33445 / s d s .2021 .11 .2 .16$

\begin{abstract}
Анотація
Розглядається досвід з організації системи державних закупівель озброєння та військової техніки в США, Великобританія, Франція та ФРН - державах, які мають сучасну провідну високорозвинену оборонну промисловість і $\epsilon$ активними учасниками світового ринку озброєнь. Надані загальна характеристика системи закупівель озброєнь, особливості побудови нормативно-правової бази щодо організації державних закупівель, парламентського та громадського контролю за ними, способи визначення постачальників, стійкі тенденції до спрощення та гнучкості функціонування систем державних закупівель озброєнь і заходи із державної підтримки виробників (постачальників) товарів, робіт, послуг. Провідний іноземний досвід може бути корисний при співставленні основних його рис із новим Законом України “Про оборонні закупівлі" від 17 липня 2020 року та продовженням удосконалення функціонування вітчизняної системи закупівель озброєнь та гармонізації її з найкращими світовими практиками.
\end{abstract}

Ключові слова: закупівлі, придбання, програми, моделі закупівель, постачальники.

\section{Постановка проблеми}

До прийняття Закону України [1] “Про оборонні закупівлі" в Україні фактично зберігалася радянська система державного оборонного замовлення (ДОЗ), яка була орієнтована на функціонування планової економіки та не повністю відповідала реальним потребам замовників та постачальників, не враховувала умови ринкових відносин та не сприяла конкуренції, прозорості та ефективності витрачання бюджетних коштів. Тому, існуюча система ДОЗ потребує ґрунтовної реформи, що передбачено Законом України “Про оборонні закупівлі". Як зазначено у Законі для його практичного застосування потребуються чисельні підзаконні правові акти 3 удосконалення системи оборонних закупівель. Для підготовки комплексних пропозицій з удосконалення діючої системи оборонних замовлень актуальним $\epsilon$ ознайомлення 3 практикою оборонних закупівель в країнах із сталими традиціями ринкових економік та потужними виробництвами озброєнь для впровадження напрацювань в правове поле оборонних закупівель в Україні.

\section{Аналіз останніх досліджень та публікацій}

Проблеми діючої в Україні системи закупівель за дОз констатовані у вітчизняних

\footnotetext{
${ }^{1}$ Corresponding author: д. екон. н., професор, начальник центру, e-mail: tim68@ukr.net, ORCID: 0000-0001-5547-6303

2 Здобувач ступеня магістр, e-mail: tim68@ukr.net

${ }^{3}$ Здобувач ступеня магістр, e-mail: tim68@ukr.net

${ }^{4}$ Здобувач ступеня магістр, e-mail: tim68@ukr.net

${ }^{5}$ Здобувач ступеня магістр, e-mail: tim68@ukr.net

${ }^{6}$ Здобувач ступеня магістр, e-mail: tim68@ukr.net
} 
нормативно-правових документах $[1,2,3]$, а також розглядаються у науковому i практичному фаховому середовищі на протязі останніх років в роботах вітчизняних вчених Горбуліна В.П., Шеховцова В.С., Шевцова А.І. [4], Бегми В.М. [5], Івановой І.М.
[6], Демидова Б.О., Коростельова О.П. [7]. Чепкова І.Б., Зубарєва В.В., Борохвостова В.К. [8] в контексті проблем ціноутворення на продукцію оборонного призначення, як предметів закупівель за доз.

\section{Постановка завдання}

Незважаючи на розпочату в Україні системну роботу з реформування системи закупівель для потреб оборони на законодавчому рівні і в науково-практичному середовищі, проблема приведення системи оборонних закупівель у відповідність до сучасних вимог ринкової економіки та для гармонізації законодавства України 3 оборонних закупівель із положеннями Директиви 2009/81/€С потребує підготовки чисельного пакету підзаконних актів прикладного призначення задля імплементації Закону України "Про оборонні закупівлі" у терміни, визначені його прикінцевими положеннями. До основних невирішених частин загальної проблеми, які мають бути розв'язані у цих актах, слід віднести:

непрозорість та неефективність процесу закупівель у єдиного постачальника в частині інформування суб'єктів ринку, проведення ринкових досліджень, планування, визначення вимог до предмету закупівель та пошуків можливої альтернативи;

необґрунтовані штучні умови обмеження (відсутності) конкуренції;

політика обмеження верхньої межі витратного ціноутворення включно з рівнем прибутку, яка декларативно має на меті захист замовника і держави від надмірних витрат, а на практиці несе корупційні ризики штучного завищення вартості складових предмету закупівель та не стимулює нових суб'єктів ринку через низький рівень чистого прибутку та відсутності гнучкості при формуванні ціни;

надмірна засекреченість та зарегульованість процесів закупівель, що унеможливлює доступ нових суб'єктів ринку до процесів планування та закупівель для потреб оборони.

Метою статті $\boldsymbol{\epsilon}$ аналіз провідного іноземного досвіду оборонних закупівель для співставлення основних його рис із новим Законом України “Про оборонні закупівлі" від 17.07.2020 року та продовженням роботи 3 удосконалення вітчизняної системи закупівель озброєнь та посилення гармонізації ї̈ 3 найкращими світовими практиками.

\section{Виклад основного матеріалу}

Розглядаються країни, які мають розвинутий ОПК та значний досвід у сфері торгівлі та державних закупівель озброєнь, а саме: США, Великобританія, Франція та ФРН (Німеччина). В цих країнах сформовані, функціонують та постійно удосконалюються цілісні національні системи закупівель для потреб оборони, що включають в себе механізми управління всім життєвим циклом об'єктів державного замовлення (придбання) для потреб оборони (стадія дослідження концептуальна стадія - стадія розроблення стадія виробництва - стадія застосування / утримання - стадія списання / утилізації).

\section{Система закупівель (придбання) ОВТ для потреб оборони США.}

Загальна характеристика. Серед країн $з$ багаторічними ринковими традиціями найбільш розвиненою $є$ система державних закупівель в США. Згідно американського законодавства відповідальність за загальне керівництво закупівельної політикою i формування контрактних систем федеральних відомств несе Управління політики федеральних закупівель - один 3 підрозділів Адміністративно-бюджетного управління при президентові США. Поряд 3 законодавством, що регулює політику 
державних закупівель, Управління видає директиви, які включаються в так звані Правила федеральних закупівель - документ досить вагомого обсягу. Додатком до цих Правил $є$ чисельна система внутрішньовідомчих інструкцій нормативного регулювання.

Законодавство, яке регламентує діяльність Управління політики федеральних закупівель, вимагає, щоб Правила федеральних закупівель [7]:

- забезпечували державних службовців, які займаються федеральними замовленнями, набором уніфікованих загальнодержавних закупівельних методик, правил і процедур, стандартних форм і статей контрактів;

- були написані хорошою, доступною мовою і мали чітку логічну структуру;

- забезпечували однозначність тлумачень нормативних положень і чітку адресність посилань до відповідних статей, пунктів, підпунктів і абзаців правових норм;

- полегшували співпрацю фірмпідрядників з федеральними органами;

- створювали умови для участі відомств, господарських структур і громадськості в процесі контролю за дотриманням Правил федеральних закупівель;

- обмежували особливі відомчі правила державних закупівель такими, які дійсно необхідні для реалізації загальнодержавної політики та загальнодержавних процедур в рамках даного відомства;

- пропонувати методики і процедури, що задовольняють специфічні потреби окремих відомств.

Тенденціїі до спрощення, гнучкості функціонування системи державних закупівель США.

За кілька десятиліть функціонування система державних закупівель США обросла великою кількістю законодавчих та інших нормативних актів і наприкінці 90-х років стала проявляти ознаки зайвої зарегульованості. Тому необхідність кардинальних змін у цій сфері стала визнаватися в документах різних відомств, організацій та комісій федерального рівня. Одним з негативних підсумків впровадження контрактної системи, заснованої на жорстких правилах а не на гнучкій сукупності методичних вказівок, стало те, що працівники федеральної контрактної системи в більшості своїй стали експертами 3 процедурних питань, а не фахівцями із закупівель зі знанням ринку і товару, що купується.

Пріоритетні напрямки постійного реформування системи державних закупівель в США бачать в наступному:

- корегування Правил федеральних закупівель з метою їх перетворення з системи жорстких правил в керівні принципи;

- зміщення повноважень щодо прийняття рішень на більш низькі, наскільки це можливо, рівні;

- усунення зайвих директивних вимог.

США мають найскладнішу та наймасштабнішу систему закупівель (придбання) для потреб оборони (табл.1) позначену у міністерстві оборони (МО) США терміном "придбання для потреб оборони (defense acquisition)" [10].

Система закупівель охоплює повний цикл розробки, виробництва та після продажного супроводження товарів військового призначення (ТВП): від прийняття рішення про створення до утилізації, включаючи законодавчу і нормативно-правову базу, яка iï регламентує. Від моменту зародження концепції нової системи озброєння та військової техніки (ОВТ) та до прийняття цієї системи на озброєння процес створення ОВТ проходить через три етапи (фази):

етап інтеграції та розвитку об'єднаних сил та засобів (Joint Capabilities Integration and Development System (JCIDS)). На цьому етапі визначаються вимоги до товарів військового призначення на основі спроможностей (capabilities-based) та тактико-технічні (технічні) характеристики ТВП, які необхідні для вирішення завдань, що прописані у стратегічних керівних документах США [11];

етапи організаційного та фінансового забезпечення: планування (складаються документи довгострокової перспективи - на 15 років), програмування (документи середньострокової перспективи - на 5 років), формування (складаються бюджетні запити - 
два роки) і виконання (виконання поточного бюджету) бюджету (Planning, Programming, Budgeting, and Execution - РРВE), відповідної систематизованої структури для прийняття рішень щодо політики, стратегії та розвитку сил і спроможностей ЗС США для виконання очікуваних завдань, розподілу бюджетних коштів, оптимального та ефективного їх використання [12];

етап придбання (Acquisition Process), що служить для розробки та / або закупівлі конкретного продукту (регулювання та управління процесом придбання) $[13,14]$.

Таблиця 1 - Закупівлі ОВТ для потреб оборони США

\begin{tabular}{|c|c|c|}
\hline $\begin{array}{c}\text { Термін, прийнятий у МO } \\
\text { США для заходів } \\
\text { закупівель для потреб } \\
\text { оборони }\end{array}$ & $\begin{array}{c}\text { Заходи, що здійснюються в рамках } \\
\text { терміну “Придбання для потреб } \\
\text { оборони” }\end{array}$ & $\begin{array}{c}\text { Закупівлі, як завершаючий етап } \\
\text { створення нової системи ОВТ }\end{array}$ \\
\hline $\begin{array}{c}\text { “Придбання для потреб } \\
\text { оборони (defense } \\
\text { acquisition)” }\end{array}$ & 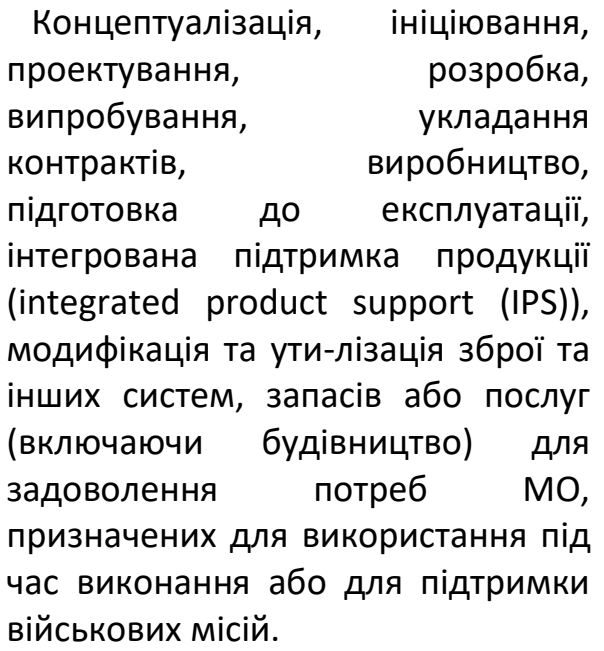 & $\begin{array}{l}\text { Етапи створення нової системи } \\
\text { ОВТ: } \\
\text { етап інтеграції та розвитку } \\
\text { об'єднаних сил та засобів (Joint } \\
\text { Capabilities Integration and } \\
\text { Development System (JCIDS)); } \\
\text { eman організаційного та } \\
\text { фінансового забезпечення: } \\
\text { планування, програмування, } \\
\text { формування, виконання; } \\
\text { етап придбання (закупівлі) } \\
\text { (Асquisition Рrocess), }\end{array}$ \\
\hline
\end{tabular}

Придбання ОВТ здійснюється за відповідними програмами, що мають певні категорії (acquisition category (ACAT)), якій присвоюється виходячи з розрахункової вартості програми, їі призначення та тип. Наприклад, MDAP - Major Defense Acquisition Programs (головні програми оборонних закупівель), MAIS - Major Automated Information Systems (головні програми закупівель автоматизаційних інформаційних систем) тощо. Існують такі категорії програм придбання ОВТ:

ACAT I (підкатегорії ACAT ID, ACAT IC) вони відносяться до типу MDAP, АCAT IA (підкатегорії АCAT IAM, АCAT IAC) відносяться до типу MAIS;

ACAT II; ACAT III та ACAT IV, останні - це скорочені програми придбання лише для ВМС та Морської піхоти [14].

Римська цифра вказує приналежність до певної категорії, чим вище цифра, тим категорія програми нижча. Від вартості програми залежить рівень контролю за ї̈ виконанням. Для керівництва кожною програмою придбання в МО США створена чітка ієрархічна система управління (рис.1). Основним виконавчим органом управління кожною програмою $є$ відділ управління Програмою (Program Office), який очолює програмний менеджер або керівник Програми (Program Manager - PM). У його підпорядкуванні знаходиться відділ управління.

Система закупівель ОВТ для потреб оборони США побудована на застосуванні децентралізованої моделі закупівель в якої відповідальність за придбання необхідних предметів, робіт та послуг за окремими складовими потреб МО та 3 С покладається на агентства МО та на види 3С. Кожне агенство MO та вид 3С має власний бюджет та проводить власний процес закупівель, у тому числі ОВТ. У більшості випадків закупівлі для окремих видів ЗС контролюються МО 
держави. Серед агенств MO найбільш значними $\epsilon$ : Агентство матеріальнотехнічного постачання (Defense Logistics Agency) [15] та Агентство передових оборонних дослідницьких проектів МО США - Defense Advanced Research Projects Agency (DARPA) [16]. Розробка правил щодо організації та управління системою закупівель ОВТ для потреб оборони, якими користуються агентства МО та види 3С, як правило, також відбувається на рівні МО. Тим не менш, ця система дозволяє окремим складовим МО та ЗС мати майже повний контроль над витратами з придбання ОВТ.

Заступник міністра оборони з питань придбання та підтримки - Under Secretary of Defense for Acquisition and Sustainment

Координує закупівельну діяльність МО США

Відповідальний виконавець з питань закупівель для потреб виду (роду) військ ЗС (Service Acquisition Executive (SAE))

Зазвичай - заступник (помічник) командувача виду (роду військ) 3С, якого призначає президент

Виконавчий керівник програми (Program Executive Officer (PEO))

Звітує перед відповідальним виконавцем з питань закупівель для виду (роду військ) зС. Може мати у своєму підпорядкуванні декілька керівників програми PMs

Керівник програми (Program Manager - PM)

Відповідає за всі аспекти програми та звітує перед виконавчим керівником програми. В деяких програмах РМ напряму звітує до відповідального виконавця

Відділ управління Програмою (Program Office)

інженери, фахівці з укладання та ведення контрактів, матеріально-технічного та фінансового забезпечення, а також персонал, який проводить на різних стадіях реалізації програми випробування технологій, підсистем і систем ОВТ і здійснює їх оцінку

Рис.1. Ієрархічне управління програмами придбання ОВТ у МО США

Розвинена законодавча база. Основною рушійною силою механізму закупівель (придбань) ОВТ $€$ грошові кошти, а законодавчим інструментом регулювання руху грошових коштів $\epsilon$ закон про затвердження бюджетних асигнувань на національну оборону - National Defense Authorization Act (NDAA), який видається кожен рік (рис.2). Законом встановлено вимоги як до конкретних програм закупівель ОВТ, так і до системи закупівель (придбання) в цій сфері загалом. Указаний закон $€$ одним 3 основних механізмів, за допомогою якого Конгрес має вплив на зміст і процедури закупівельних процесів.

Особливістю закупівельної практики США $\epsilon$ наявність уніфікованого зводу законодавчих та підзаконних актів, які регулюють Правила закупівель для федеральних потреб [17] Federal Acquisition Regulations (FAR) [попередне посилання]. 
Уніфікований звід законодавчих та підзаконних актів, які регулюють Правила закупівель для федеральних потреб - Federal

Acquisition Regulations (FAR)

Базові закони для федеральних закупівель

\begin{tabular}{|c|}
\hline Закон про затвердження \\
бюджетних асигнувань на \\
національну оборону - National \\
Defense Authorization Act (NDAA) \\
Видається кожен рік. \\
Встановлено вимоги до \\
конкретних програм закупівель і \\
до системи закупівель ОВТ \\
загалом. Є одним з основних \\
механізмів впливу Конгресу на \\
зміст і процедури закупівельних \\
процесів \\
\end{tabular}

\begin{tabular}{|c|}
\hline Закон про \\
конкуренцію у \\
контрактах \\
(Competition in \\
Contracting Act) \\
посилив конкуренцію \\
у федеральних \\
закупівлях та \\
встановив \\
різноманітні \\
процедури \\
придбання, \\
включаючи \\
конкурентні \\
переговори \\
\hline
\end{tabular}

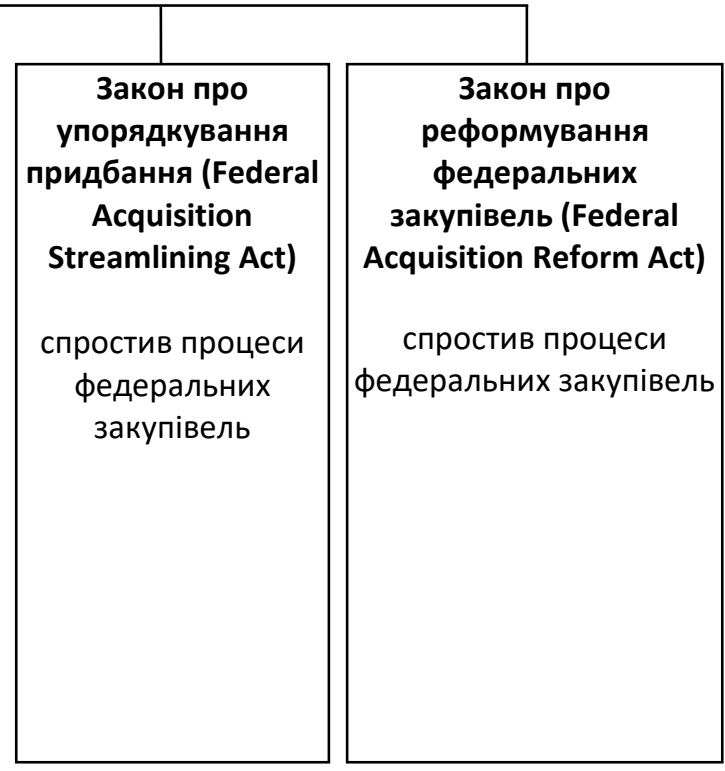

Рис. 2. Базові закони для федеральних закупівель США Способи визначення постачальників.

У відповідності до FAR способами визначення постачальників, які застосовуються в США, є: відкриті торги; етапні торги; прямі переговори; спрощені способи закупівель (рис. 3).

\section{Способи визначення постачальників в США}

засновані на принципах: економія коштів, зниження ризиків неефективності закупівель, підвищення прозорості процедур

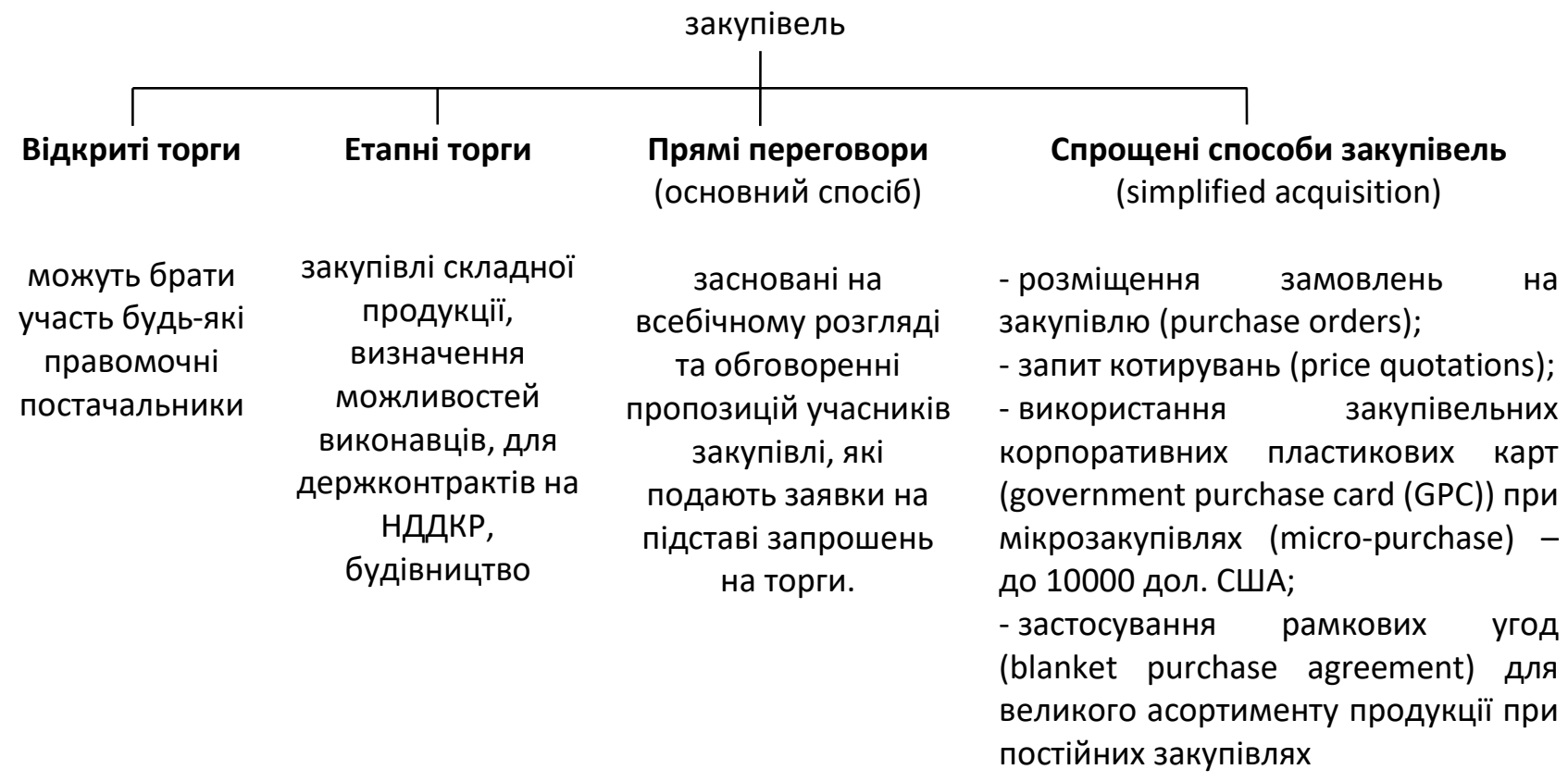

Рис. 3. Способи визначення постачальників в США 
В свою чергу, задля регламентації специфіки використання різних способів визначення постачальників для оборонних потреб існує додаток до FAR - Правила закупівель для потреб оборони (Defense Federal Acquisition Regulation Supplement (DFARS)) [18].

Так, наприклад, здійснення спрощених способів закупівель для оборонних потреб з використанням корпоративних пластикових карт допускається для закупівель, вартість яких перевищує поріг мікро-закупівель, але не більше 25000 дол. США. Крім того, закупівля може здійснюватися, якщо продукція купується за межами США та не передбачає доступ до секретної інформації (DFARS 213.3.) [19]. Закупівлі у єдиного постачальника допускаються тільки у випадках, коли існує тільки єдиний виробник та постачальник бажаного товару, роботи чи послуги у галузі та ніякі інші не задовольняють вимоги замовника (DFARS 206.3.) [20]. DFARS застосовуються тільки в поєднанні зі FAR та виключно для закупівель продукції оборонного призначення. Базуючись на вимогах FAR невід'ємною частиною всіх рішень щодо закупівель $€$ два найважливіші принципи це: економія коштів та конкурентні процеси.

Для зниження ризиків неефективності роботи системи закупівлі (придбання) МО США, а відповідно підвищенню прозорості та проведенню належного нагляду окрім налагоджених процедур роботи системи внутрішнього контролю та аудиту під наглядом Головного інспектора МО США (Inspector General - IG) система знаходиться під моніторингом та наглядом Рахункової палати США (Government Accountability Office -GAO), яка періодично публікує звіти та забезпечує Парламентський та громадський контроль.

У системі придбання МО США активно застосовується державно-приватне партнерство, акцент робиться на співробітництві малого бізнесу та державних науково-дослідних установ США, які працюють на МO для проведення науководослідних та дослідно-конструкторських робіт (НДДКР) і реалізації ДОЗ з ОВТ. Діючі на даний час державні програми залучення малого бізнесу (small business (SB)) до державних оборонних закупівель "Малий інноваційний бізнес" (SB Innovation Research (SBIR)) та "Передача технологій малим бізнесом" (SB Technology Transfer (STTR)) [21] - це програми, в яких MO США $є$ активним учасником. Програми SBIR і STTR - програми уряду США, які координуються Агентством зі справ малого бізнесу (SBA).

\section{Країни Європейського союзу}

У країнах Європейського союзу (ЄC) основу державних закупівель складають конкурсні процедури. Окрім відкритих та закритих, одно- та двоетапних конкурсів, запиту котирувань, використовують конкурентні переговори та запит пропозицій. Для застосування зазначених способів, крім критерію найнижчої ціни, використовуються критерії екологічної безпеки, соціальної значущості, благонадійності попередніх взаємовідносин з постачальником, а також можливість оцінювати вигоду від придбання товару протягом усього його життєвого циклу.

Закупівлі в сфері оборони ЄС достатньо жорстко регламентовані із врахуванням національних інтересів та законодавств країнчленів ЄС Директивою 2014/24/ЄС від 26.02.2014 про державні закупівлі (Directive 2014/24/EU) та Директивою 2009/81/ЄС від 13.07.2009 про координування процедур укладення окремих видів контрактів на виконання робіт, закупівлю товарів і надання послуг у сфері оборони та безпеки (Directive 2009/81/EC) [22]. Національне законодавство країн-членів $\in C$ відповідно адаптувало законодавство $€ C$ та застосовує правила які там визначені, з де-якими виключеннями, щодо закупівель вартість, яких досягає або перевищує певний поріг. Порогові значення регулярно оновлюються законодавством $Є C$, на даний час це: на виконання робіт - 5548 тис. євро; а на товари та послуги в секторі оборони та безпеки - 443 тис. євро [23].

Ще однією загальною особливістю, у відповідності до закупівельного права $€ С, \epsilon$ зобов'язання до публікації сповіщення щодо проведення торгів на укладення договорів 
щодо поставки товарів і послуг військового та спеціального призначення (contract notice) в Офіційному віснику Європейського Союзу (OJEU), окрім випадків, де процедура не передбачає публікації сповіщення.

Багато країн Європи створили власні централізовані державні органи для контролю за процесом закупівель для потреб оборони. Ці організації несуть відповідальність за придбання всіх ОВТ, необхідних для ЗС своєї країни. Більшість 3 цих організацій працюють у складі МО країни, хоча вони, як правило, залишаються незалежними від військових та мають власний бюджет. Однак у деяких випадках ці закупівельні органи функціонують як незалежні урядові відомства чи організації. Великобританія, Франція та Німеччина належать до країн, які проводять закупівлі ОВТ для потреб оборони через єдиний державний орган.

Особливості державних закупівель у Великобританії. Відправною точкою формування будь-яких управлінських рішень щодо закупівель (придбань) для потреб МО Великобританії $€$ бачення прем'єр-міністра та Ради національної безпеки на пріоритети розвитку спроможностей МО та управління ними з урахуванням життєого циклу об'єктів закупівель (ОВТ) заради приведення спроможностей у відповідність стратегічним вимогам і цілям, які визначають оборонну політику держави. Відповідно і етапи життєвого циклу ОВТ КОДВУ (CADMID) - Концепція (Concept) (опис та визначення вимог), Оцінювання (Assessment) (включає етап проведення тендеру та фази випробувань), Демонстрація (Demonstration), Виробництво (Manufacture), Обслуговування (In-service), та нарешті, Утилізація (Disposal) формуються у суворій відповідності до вимог управління спроможностями МО Великобританії.

Основні програми розробки та придбання OBT детально описані в Плані ОВТ (Defence equipment plan), який складається на 10 років [24].

У Великобританії придбанням ОВТ для всіх видів ЗС займається Організація з розробки та підтримки військової техніки (Defence
Equipment and Support Organization - DE\&S), яке діє як торгівельний орган МО, що працює на його замовлення та централізовано закуповує та постачає ОВТ а також послуги 3 обслуговування ОВТ. Організація тісно співпрацює з ОПК, в тому числі через реалізацію ініціатив державно-приватного партнерства (partnering agreements and private finance initiatives) [25].

Управляється та координується система придбання ОВТ через роботу Об'єднаних проектних груп (Integrated Project Team, IPT), які здійснюють управління окремими оборонними проектами або групами невеликих проектів. До складу кожної проектної групи входять представники з усіх підрозділів МО, видів 3С, які $\epsilon$ замовниками OBT, а також представники ОПК, як підрядникавиконавця проекту.

Як відомо, Великобританія до 2020 року перебувала у складі $\in C$ i на неї розповсюджувалося законодавство $€ C$ щодо державних закупівель, а саме - Правила укладення державних контрактів в області оборони і безпеки 2011 року (The Defence and Security Public Contracts Regulations 2011, DSPCR 2011) [26]. Основна відмінність спеціального законодавства стосовно закупівель для потреб оборони від загальних правил укладення контрактів полягає в тому, що 3 нього виключена відкрита процедура проведення торгів (open procedure) (рис. 4).

Під дію вищезазначених Правил підпадають договори на:

поставку військового обладнання, включаючи комплектуючі та запчастини;

поставку спеціального обладнання, включаючи комплектуючі та запчастини;

поставку товарів, надання послуг та виконання робіт, необхідних протягом усього життвого циклу ОВТ та спеціальної техніки;

поставку товарів, надання послуг та виконання робіт, необхідних для досягнення конкретних військових і спеціальних цілей.

При цьому, сума договору повинна бути рівною або перевищувати поріг закупівель у відповідності до закупівельного законодавства $\in C$, який періодично переглядається [26; 27]. 


\section{Способи відбору постачальників в Великобританії}

(особливість закупівель для потреб оборони - виключена відкрита прочедура

проведення торгів (ореn procedure)

найбільш типові

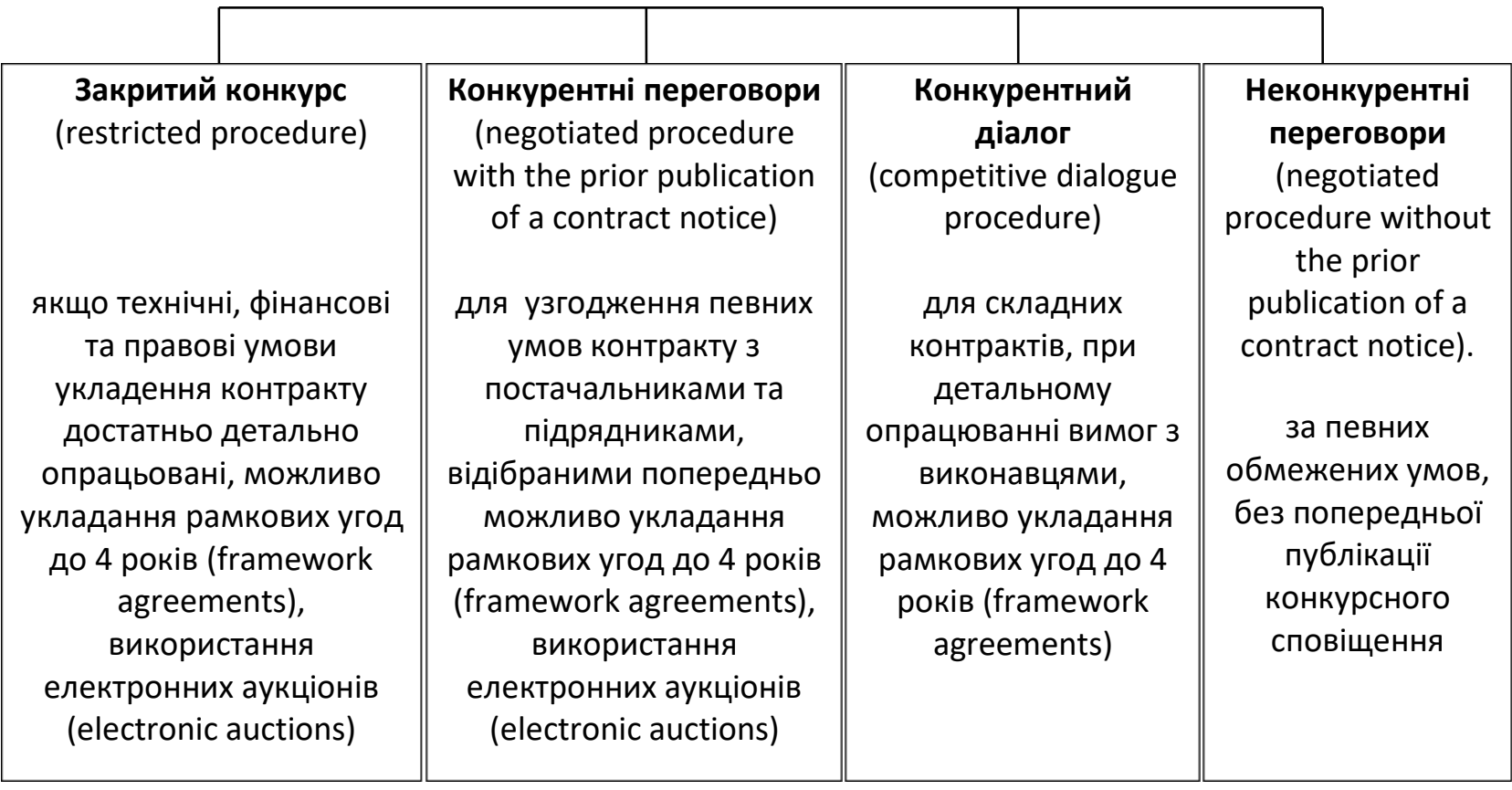

Рис. 4. Способи відбору постачальників в Великобританії

щодо застосування процедури неконкурентних переговорів, то її вибір має бути застосований, тільки за певних обмежених умов (Умовами є: відсутність тендерних пропозицій, на раніше подані заявки на проведення відповідних процедур у вигляді закритого конкурсу, конкурентних переговорів або конкурентного діалогу; коли терміни подачі для конкурентних процедур несумісні з наявними внаслідок кризи; коли 3 технічних причин або з причин, пов'язаних із захистом виключних прав на предмет закупівлі, договір може бути укладений лише певним економічним оператором (тобто постачальник) тощо.). Замовник особисто визначає коло можливих претендентів на держзамовлення з числа, як правило, вже добре знайомих йому постачальників.

Закон про реформу оборони 2014 року (Defence Reform Act) встановив нові підходи для проведення неконкурентних закупівель [28],та створив Управління 3 питань закупівель з єдиного джерела (Single Source Regulations Office (SSRO)) як незалежний регуляторний орган у вказаній сфері [29]. До функцій SSRO входить надання рекомендацій щодо базової норми прибутку, допустимих витрат; надання висновків або рішень щодо питань закупівель з єдиного джерела. Однак, міжнародні договори; договори на придбання 3 метою проведення розвідувальної діяльності; договори на придбання, управління або утримання земель чи будівель та контракти, укладені в рамках сумісної міжнародної оборонної програми, заснованої на дослідженнях і розробках не підпадають під регуляторні рамки SSRO. Крім того, міністр оборони Великобританії має повноваження звільняти закупівельні контракти від регуляторних рамок SSRO [30].

Фахівці МО, залучені до закупівельної діяльності, керуються вимогами Закону про боротьбу з хабарництвом від 2010 року (Bribery Act) [31]. Використовуючи вебпортали Оборонні контракти онлайн (Defence Contracts Online (DCO)) та Пошук контрактів (Contracts Finder) MO 
Великобританії надає всім своїм наявним та потенційним постачальникам (як великим, так і малим компаніям) безкоштовний доступ до всіх своїх опублікованих закупівельних тендерних та контрактних об'яв сума, яких перевищує 10 тис. ф. ст. [32].

Закупівлі МО Великобританії вартістю нижче порогових значень визначених у Правилах 2011 року регулюються внутрішньовідомчими керівними документами щодо закупівель з низькою вартістю. Але для закупівель вартістю більше 5 тис. ф. ст., але менше 1 млн. ф. ст. рекомендовано використовувати шаблонні стандартизовані контракти (Standardised Contracting Templates) [33; 34].

Готуючись до виходу із $\in \mathrm{C}$, Уряд Великобританії у грудні 2018 року розробив законопроект про внесення змін до Правил укладення державних контрактів в області оборони і безпеки 2011 року з врахуванням виходу країни з ЄC [35]. Однак у зв'язку із відомим затягуванням процедури виходу про прийняття цього законопроекту поки що не повідомлялося.
Особливості державних закупівель у Франції. Система організації державних закупівель во Франції також заснована на законодавстві $\in C$. Головним нормативноправовим актом $\epsilon$ Кодекс громадського порядку (фр. Code de la commande publique), в якому регламентується система держаних закупівель для всіх рівнів та сфер [36] (рис. 5). Формалізовані процедури для закупівель у сфері оборони та безпеки - визначені у Directive 2009/81/EC [37].

У Франції процес закупівель забезпечений контролем над бюджетними витратами на всіх етапах. Всі відомства і органи влади формують підрозділи по закупкам, які укладають і виконують контракти. Визначення постачальників у Франції здійснюється за допомогою відкритого або закритого конкурсу.

Стратегічні пріоритети в галузі оборони і безпеки Франції визначаються на кожні 15 років у так званій Білій книзі з оборони (французька доктрина з питань оборони і національної безпеки) [38; 39].

\begin{tabular}{|c|c|c|c|c|c|}
\hline \multicolumn{6}{|c|}{ Організація державних закупівель у Франції } \\
\hline основні & \multicolumn{2}{|c|}{ закупівельні процедури } & \multicolumn{2}{|c|}{ визначення постачальників } & \\
\hline \multicolumn{2}{|c|}{$\begin{array}{c}\text { Формалізовані } \\
\text { процедури } \\
\text { для закупівель, } \\
\text { вартість яких } \\
\text { дорівнює пороговим } \\
\text { значенням ЄС та } \\
\text { вище }\end{array}$} & $\begin{array}{c}\text { Відповідні процедури } \\
\text { для закупівель вартістю нижче } \\
\text { порогових значень ЄС, але } \\
\text { вище } 25 \text { тис. евро передбачають } \\
\text { вільне визначення публічності, } \\
\text { умов процедури відповідно до } \\
\text { принципів рівного ставлення, } \\
\text { відкритого доступу до процедур } \\
\text { та прозорості. }\end{array}$ & $\begin{array}{c}\text { Відкритий } \\
\text { конкурс }\end{array}$ & \multicolumn{2}{|c|}{$\begin{array}{c}\text { Закритий конкурс } \\
\text { обмежене коло } \\
\text { постачальників, } \\
\text { предмет конкурсу } \\
\text { пов'язаний із } \\
\text { нацбезпекою, } \\
\text { становить державну } \\
\text { таємниця }\end{array}$} \\
\hline
\end{tabular}

Рис. 5. Способи визначення постачальників у Франції

Важлива особливість! Закон про військові програми закупівель ОВТ застосовується на п'ять років, який конкретизується в Законі про бюджет на поточний фінансовий рік. А тому виробники мають тверді замовлення в середньостроковій перспективі, маючи при цьому можливість розвивати свою виробничу базу та здійснювати власні НДДКР.

Формування замовлень на придбання ОВТ входить в компетенцію МО. Діяльність МО знаходиться під постійним контролем прем'єр-міністра і президента Франції. Це 
визначає строго централізоване керівництво оборонним замовленням з боку держави.

Закупівлі ОВТ здійснює Генеральна дирекція 3 озброєнь (фр. Direction générale de l'armement), на неї також покладено відповідальність щодо сприяння розвитку експортних продажів французького ОПК [40; 41].

Франція ще на початку XXI століття провела інноваційну реформу, створивши у 2005 році Національну агенцію 3 питань досліджень (Agence Nationale de la Recherche, ANR) для вдосконалення фінансування фундаментальних і прикладних досліджень та інновацій. Також у 2005 році було створено Приватну компанію з делегацією на державну службу, яка фінансово підтримувала розвиток інноваційної діяльності французьких малих та середніх підприємств (ㅌuvre suisse d'entraide ouvrière, OSEO), [42] та у 2013 році увійшла до складу Державного інвестиційного банку (Bpifrance). Тобто державно-приватне партнерство в оборонній сфері Франції вже давно $€$ рушійним механізмом інноваційної діяльності в оборонній сфері.

Особливості державних закупівель у ФРН. Закупівельна система ФРН також базується на закупівельному праві ЄС (рис.6).

Закупівлі, вартісної категорії рівної та вище закупівельного порогу законодавства ЄС [43] регулюються Законом проти обмеження конкуренції (Gesetz gegen Wettbewerbsbeschränkungen - GWB). Закупівлі, вартість яких нижче порогів $\in C$, регулюються бюджетним законодавством (Bundeshaushaltsordnung - ВНО) ФРН, яке $\epsilon$ менш регульованим та більш гнучким $[44,45]$.

\section{Організація державних закупівель у ФРН}

(більш проста ніж у США та Франції)

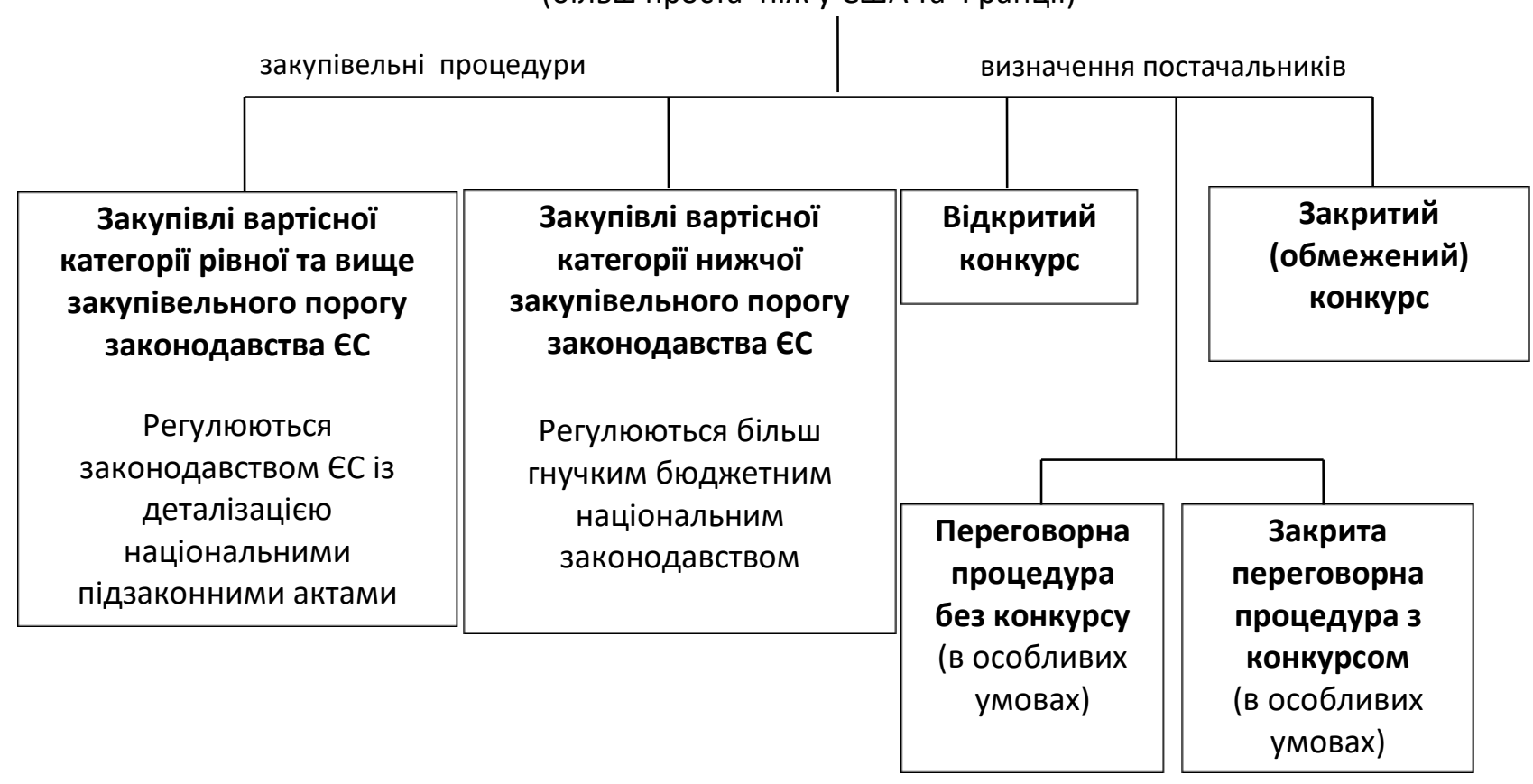

Рис. 6. Способи визначення постачальників у ФРН

Закупівлі, вартісної категорії рівної та вище закупівельного порогу законодавства ЄС [46] регулюються Законом проти обмеження конкуренції (Gesetz gegen Wettbewerbsbeschränkungen - GWB). Закупівлі, вартість яких нижче порогів $\in C$, регулюються бюджетним законодавством (Bundeshaushaltsordnung - ВНО) ФРН, яке $\epsilon$ менш регульованим та більш гнучким $[47,48]$.

У 2019 році прийнятий Закон про прискорені закупівлі в області оборони і безпеки та Указ про оптимізацію статистики 
закупівель [49]. Вказані акти обумовлюють, що єдиним органом, який уповноважений збирати статистичні дані щодо закупівель $\epsilon$ Федеральне статистичне управління, та може застосовуватися переговорна процедура без участі у конкурсі, або закрита процедура, замість переговорної процедури з конкурсом [50].

Законодавство $€ С$ застосовується лише в тому випадку, якщо вартість контракту досягає або перевищує поріг, який встановлений у закупівельному законодавстві ЄC [51].

Організація закупівельної діяльності в 3С ФРН визначається положеннями конституції країни, згідно з якими бундесвер має двокомпонентну організаційну структуру i складається зі збройних сил і військової адміністрації (цивільної складової) 3 власними нижчими адміністративними ланками. Завданнями $\mathrm{MO} \in$ управління особовим складом і безпосередне задоволення матеріальних потреб 3С, а сааме - речове та продовольче забезпечення військовослужбовців та управління нерухомістю. Таким чином, органи військового управління та військові підрозділи, що входять до складу 3С, не здійснюють закупівельну діяльність, оскільки вона віднесена до відання МО.

Причинами закріплення такого підходу на конституційному рівні $€$ бажання звільнити 3 С від рішення адміністративних і господарських завдань, а також виключити можливість втрати над ними демократичного контролю.

Здійснення закупівельної діяльності продукції військового призначення в МО ФРН покладене на Федеральне відомство із закупівлі та експлуатації ОВТ, АСУ та зв'язку бундесверу (Bundesamt fur Ausrustung, Informationstechnik und Nutzung der
Bundeswehr - BAAINBw). Це більш проста схема, ніж у США та Франції.

BAAINBw (м. Кобленц) організаційно підпорядковується управлінню МO (Abteilung Ausrustung, Informationstechnik und Nutzung AIN), яке відповідає за планування, координацію і контроль закупівельної діяльності як на національному, так і на міжнародному ринку.

Підготовкою завдань на поставку товарів (виконання робіт, надання послуг) займаються споживачі продукції, що закуповується (наприклад, військово-морські сили ФРН) і військове відомство. 3 цією метою створюються спільні робочі групи з вивчення потенційних можливостей (Capability Analysis Integrated Working Groups), за прикладом МO Великобританії, до складу яких входять представники різних підрозділів МО і ВС та склад груп може варіюватися від етапу до етапу. Ці групи визначають існуючі потреби, можливі шляхи їх задоволення з урахуванням наявних у організацій обороннопромислового комплексу виробничих потужностей і фахівців і в кінцевому рахунку вимоги до продукції, що закуповується.

При закупівлі BAAINBw не тільки визначає постачальників, але і здійснює приймання поставленої продукції, що дозволяє знизити ризик змови між споживачами продукції оборонного призначення (ПОП) i їі виробниками i, як наслідок, неефективного витрачання бюджетних коштів.

BAAINBW наділене повноваженнями центрального закупівельного органу щодо укладення рамкових угод в інтересах кількох федеральних відомств на поставку товарів, що входять в наступні товарні групи: пальномастильні матеріали; освітлювальні прилади і джерела електроживлення; інструменти та комунікаційні технології.

\section{Висновки}

1. У провідних учасників світового ринку озброєнь - США, Франція, Великобританія та ФРН функціонують та постійно удосконалюються цілісні національні закупівельні системи для потреб оборони, що охоплюють і контролюють повний життєвий цикл товарів військового призначення від прийняття рішення про їх створення до утилізації, включаючи нормативно-правову базу, яка регламентує закупівлі i супроводження життєвого циклу товарів. Закупівлі розглядаються як завершення етапу 
створення нових систем ОВТ.

2. Системи закупівель озброєнь функціонують в рамках організаційно структурованих та фінансово забезпечених програм придбання OBT, які розподілені на певні категорії відповідно до розрахункової вартості програми. Від вартості програми залежить рівень контролю за її виконанням.

3. Для керівництва кожною програмою придбання ОВТ в розглянутих країнах створені власні системи управління, розраховані на національний державний устрій. Але характерним для систем управління є чітка ієрархія побудови інстанцій та фахівців систем управління, організації фахового, парламентського і громадського контролю та звітності щодо виконання програм закупівель (придбання) ОВТ, здійснення управлінських впливів з боку замовників та органів законодавчої та виконавчої влади на зміст i процедури закупівельних процесів.

4. Особливістю системи закупівель ОВТ для потреб оборони США, як найпотужнішого В світі виробника, покупця та продавця озброєнь, є застосування децентралізованої моделі закупівель, в якої відповідальність за придбання необхідних предметів, робіт та послуг за окремими складовими потреб МО та 3С покладається на агентства МO та на види 3С. Кожне агентство МО та вид 3С має власний бюджет та проводить власний процес закупівель, але під контролем МO держави та за правилами, встановленими МО. Координує закупівельну діяльність МО США посадовець у рангу заступника міністра оборони з питань придбання та підтримки.

5. Функціонування систем закупівель озброєнь у аналізованих державах регламентовано базою уніфікованих законодавчих та підзаконних актів, якими встановлено вимоги як до конкретних програм закупівель так і до систем закупівель (придбання) загалом. Незважаючи на великій багаторічний досвід функціонування оборонних виробництв в ринкових умовах та якісно напрацьовані нормативно-правові бази з організації оборонних закупівель, спостерігаються тенденції до спрощення та гнучкості функціонування системи державних закупівель. Йде постійне удосконалення керівних документів з закупівель озброєнь 3 метою перетворення їх з системи жорстких правил в керівні принципи, зміщення повноважень на більш низькі управвлінськи рівні, усунення зайвих директивних вимог $\mathrm{i}$ впровадження заходів, спрямованих на підвищення прозорості, усунення корупції та економію коштів.

6. Визначення

постачальників в досліджуваних системах закупівель здійснюється, як правило, шляхом конкурсних торгів (конкурсів), які В залежності від предмету конкурсу та часових умов здійснення підрозділяються на відкриті і закриті, можуть проводиться в один або два етапи. У відкритих конкурсах можуть брати участь будь-які правомочні постачальники. Закриті конкурси застосовуються, коли об'єкт закупівлі може бути поставлений лише певним колом постачальників, або процедура закупівель має відношення до національної безпеки або предмет конкурсу становить державну таємницю.

Однак, у національних законодавствах діють i інші способи визначення постачальників озброєнь, які відповідають державному устрою, обсягам закупівель та національним правилам загальних державних закупівель.

Наприклад, у США застосовуються відкриті торги, етапні торги, прямі переговори, спрощені способи закупівель. В країнах $Є C$ системи закупівель побудовані на закупівельному праві ЄС. В Великобританії використовуються закритий конкурс, конкурентні переговори, конкурентний діалог, неконкурентні переговори. У Франції прийняті відкриті конкурси, закриті конкурси. У ФРН проводяться відкриті, закриті та обмежені конкурси а також, при особливих умовах, переговорні процедури без конкурсу та закриті переговорні процедури 3 конкурсом.

Вибір виду конкурсу залежить також від вартості контрактації закупівельних 
процедур, які підрозділяються на дві категорії: ті, що перевищують закупівельний поріг законодавства $\in C$, та ті, що не перевищують.

7. Закупівлі в сфері оборони в країнах $\in C$ достатньо жорстко регламентовані із врахуванням національних інтересів та законодавств країн-членів ЄC. Для застосування зазначених способів закупівель, крім критерію найнижчої ціни, використовуються критерії екологічної безпеки, соціальної значущості, благонадійності попередніх взаємовідносин з постачальником, а також можливість оцінювати вигоду від придбання товару протягом усього його життєвого циклу.

Провідний іноземний досвід може бути корисний при співставленні основних його рис із новим Законом України “Про оборонні закупівлі" від 17. 07.2020 року та продовженням роботи з удосконалення вітчизняної системи закупівель озброєнь та гармонізації ії 3 найкращими світовими практиками.

\section{Список використаних джерел}

1. Про оборонні закупівлі: Закон України від 17.07.2020 року, № 808-ІХ.

2. Про публічні закупівлі: Закон України, 25.12. 2015 року, № 922-VIII.

3. Стратегія розвитку обороннопромислового комплексу України на період до 2028 року. Розпорядження Кабінету Міністрів України від 20.06.2018 p. № 442-p.

4. Горбулін В. П., Шеховцов В. С., Шевцов А. І. Проблеми державного регулювання цін на продукцію оборонно-промислового комплексу України. Стратегічні пріopumemu. №2(31). Київ, НІСД, 2014.

5. Бегма В. М. Нормативно-правове та інституційне забезпечення міжнародного воєнно-економічного співробітництва України. Стратегічні пріоритети. №4(37). Київ, НІСД, 2015.

6. Іванова І. М. Особливості формування вартості продукції оборонного призначення. Cmpameгічні пріоритети. №2. Київ, НІСД, 2016.

7. Методические основы системных исследований и решения проблем технического оснащения вооруженных сил государства: монография / Гриб Д.А. и др.; под ред Б.А. Демидова и О.П.Коростелева. Киев: Стилос, 2016. 654 с., (639 с.)

8. Чепков І. Б., Зубарєв В.В., Борохвостов В.К. [та ін.]., Теорія озброєння. Науковотехнічні проблеми та завдання. Київ: 2018.

9. Звіт про науково-дослідну роботу “Обґрунтування рекомендацій щодо підвищення ефективності управління системою закупівель озброєння та військової техніки Міністерства оборони України", шифр "Ефективність-3". Національний університет оборони України імені Івана Черняховського, 2020 р.

10. DAU. 'Glossary of Defense Acquisition Acronyms and Terms'. URL: https://www.dau.mil/glossary/Pages/Glossa ry.aspx\#!term|A|26772.

11. CJCSI 5123.01H August 31, 2018. Charter of the Joint Requirements Oversight Council (JROC) and Implementation of the Joint Capabilities Integration and Development System (JCIDS) URL: https://www.jcs.mil/Portals/36/Documents/ Library/Instructions/CJCSI\%205123.01H.pdf? ver=2018-10-26-163922-137.

12. DoDD 7045.14. January 25. 2013. Incorporating Change 1, August 29, 2017, The Planning, Programming, Budgeting, and Execution (PPBE) URL: https://www.esd.whs.mil/Portals/54/Docum ents/DD/issuances/dodd/704514p.pdf?ver= 2017-08-29-132032-353

13. DoDD 5000.01. May 12. 2003. Incorporating Change 2, August 31, 2018. URL: https://www.esd.whs.mil/Portals/54/Docum ents/DD/ issuances/dodd/500001p.pdf

14. DoDI 5000.02. January 7. 2015. Incorporating Change 4, August 10. 2017. URL: https://www.esd.whs.mil/Portals/54/ Documents/DD/issuances/dodi/500002_dod i_2015.pdf 
15. Defense Logistics Agency. URL: https://www.dla.mil/AtaGlance/.

16. Defense Advanced Research Projects Agency. URL: https://www.darpa.mil.

17. Federal Acquisition Regulation. URL: https://www.in.gov/indiana-ptac/files/FAR. pdf.

18. DFARS. URL: https://www.acq.osd.mil/ dpap/dars/dfarspgi/current/

19. DFARS 213.3. URL: http://www.acq.osd.mil/ dpap/dars/dfarspgi/current/

20. DFARS 206.3. URL: http://www.acq.osd.mil/ dpap/dars/dfarspgi/current/

21. Small Business Innovation Research та Small Business Technology Transfer. URL: https://www.sbir.gov/about

22. DIRECTIVE 2009/81/EC OF THE EUROPEAN PARLIAMENT AND OF THE COUNCIL of 13 July 2009. URL: https://eur-lex.europa.eu/legalcontent/EN/TXT/?uri=celex\%3A32009L0081

23. Thresholds for Defence Directive 2009/81/EC. URL: https://ec.europa.eu/growth/single-market/ public-procurement/rules-implementation/ thresholds_en

24. The defence equipment plan 2018. URL: https://www.gov.uk/government/publicatio ns/the-defence-equipment-plan-2018.

25. Defence Equipment and Support (DE\&S). Commons Briefing papers SN06903 (2014), House of Commons. URL: https://researchbriefings.parliament.uk/Res earchBriefing/Summary/SN06903

26. The Defence and Security Public Contracts Regulations 2011. URL: http://www.legislation.gov.uk/uksi/2011/18 48/made

27. 2018 Procurement Thresholds. URL: https://www.contracts.mod.uk/supplyingdefenceojeu-procurement-thresholds-2018/

28. The Single Source Contract (Amendment) (No. 2) Regulations 2018. URL: http://www.legislation.gov.uk/uksi/2018/13 50/made

29. Ministry of Defence, "An Overview: Single Source Procurement Framework", June 2014. URL: http://www.metasums.co.uk/uploads/ asset_file/Overview\%20\%20-\%20single\%20
source\%20procurementof\%20Framework.p df

30. An introduction to defence procurement. Commons Library Briefing, 28 January 2019. URL: https://researchbriefings.parliament. uk/ResearchBriefing/Summary/CBP-8486\# fullreport

31. Bribery Act 2010 URL: https://www.legislation.gov.uk/ukpga/2010 $/ 23 /$ contents

32. Procurement at MOD. URL: https://www.gov.uk/government/organisati ons/ministry-of-defence/about/ procurement

33. Below Threshold Procurement under PCR 2015. MOD Commercial. An Essential Guide for Commercial Staff. September 2019. URL: https://www.aof.mod.uk/aofcontent/tactica l/toolkit/downloads/eupcr2015/eupcr2015_ below_threshold_guide.pdf

34. Low Value Requirements < f1M. URL: https://www.aof.mod.uk/aofcontent/tactica l/toolkit/downloads/lovare/lovare_cps.pdf?z oom_highlight $=\% 22$ procurement+of+low+va lue $\% 22$ \#search=\%22procurement $\% 20$ of\%20l ow\%20value\%22

35. The Defence and Security Public Contracts (Amendment) (EU Exit) Regulations 2019. URL: http://www.legislation.gov.uk/ukdsi/ 2019/9780111176764

36. Code de la commande publique URL: http://www.marche-public.fr/ccp/ccp-planreglementaire.htm.

37. France: Public Procurement 2019. URL: https://iclg.com/practice-areas/publicprocurement-laws-and-regulations/france

38. The French White Paper on defence and national security URL: https://www.cfr.org/ content/publications/attachments/Dossier de_presse_LBlanc_DSN_en_anglais.pdf

39. White Paper on Defence and National Security URL: https://otan.delegfrance.org/ White-Paper-on-Defence-and-NationalSecurity

40. Présentation de la direction générale de l'armement URL: https://www.defense.gouv.fr/dga/ladga2/missions/presentation-de-la-direction- 
generale-de-I-armement.

41. Ethan B. Kapstein. Smart Defense Acquisition: Learning from French Procurement Reform. URL: https://www.files.ethz.ch/isn/110730/2009 _12_CNAS\%20Policy\%20Brief\%20\%20defense\%20acquisition_1.pdf (дата звернення: 05.10.2019).

42. Олена Саліхова Досвід Франції та Німеччини щодо створення умов для піднесення рівня національних високотехнологічних виробництв. Економіст. 2011. №11. С. 67-70. URL: http://www.irbis-nbuv.gov.ua/cgibin/irbis_nbuv/cgiirbis_64.exe?C21COM=2\& I21DBN=UJRN\&P21DBN=UJRN\&IMAGE_FILE _DOWNLOAD=1\&Image_file_name=PDF/eco n_2011_11_19.pdf (дата звернення: 05.10.2019)

43. Grundlagen der Beschaffung. Bundesamt fur Ausrustung, Informationstechnik und Nutzung der Bundeswehr. URL: https://www.baainbw.de.

44. Thomas Solbach. Public Procurement in Germany. Workshop on the Public Procurement Strategy. European Parliament. Brussels, February'19, 2018. URL: http://www.europarl.europa.eu/cmsdata/1 38604/06\%20-\%20SOLBACH\%20\%20Public\%20Procurement\%20in\%20Germa ny.pdf

45. Germany: Public Procurement 2019. URL: https://iclg.com/practice-areas/publicprocurement-laws-andregulations/germany.

46. Grundlagen der Beschaffung. Bundesamt fur Ausrustung, Informationstechnik und Nutzung der Bundeswehr. URL: https://www.baainbw.de (дата звернення: 15.10.2019).
47. Thomas Solbach. Public Procurement in Germany. Workshop on the Public Procurement Strategy. European Parliament. Brussels, February'19, 2018. URL: http://www.europarl.europa.eu/cmsdata/1 38604/06\%20-\%20SOLBACH\%20\%20Public\%20Procurement\%20in\%20Germa ny.pdf

48. Germany: Public Procurement 2019. URL: https://iclg.com/practice-areas/publicprocurement-laws-andregulations/germany.

49. Regierung beschließt Gesetz für schnellere Beschaffung URL: https://www.bmvg.de/de/aktuelles/regieru ng-beschliesst-gesetz-fuer-schnellerebeschaffung-144102

50. Kabinettsentwurf eines Gesetzes zur beschleunigten Beschaffung im Bereich der Verteidigung und Sicherheit und zur Optimierung der Vergabestatistik URL: http://www.forum-vergabe.de/newsdetail/kabinettsentwurf-eines-gesetzes-zurbeschleunigten-beschaffung-im-bereich-derverteidigung-und-sicherheit-und-zuroptimierung-der-vergabestatistik-7961/

51. Germany: Public Procurement 2019. URL: https://iclg.com/practice-areas/publicprocurement-laws-andregulations/germany.

52. Ткач І. М. Концептуальні засади воєнноекономічної безпеки держави : монографрія. Київ : НУОУ ім. І. Черняховського, 2018. 312 C. ISBN 978-617-7187-19-5

53. Parkhomenko, P., Lavruk, M., Tkach, I., \& Skurinevska, L. (2020). Problems pricing for defense products and solutions. Journal of Scientific Papers "Social Development and Security», 10(3), 75-92. DOI: $10.33445 /$ sds.2020.10.3.7

\title{
Анализ международного опыта по организации системы государственных закупок вооружения и военной техники
}

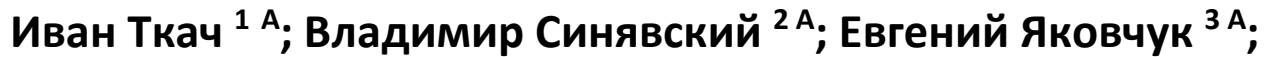 \\ Михаил Рудый ${ }^{4}$; Владимир Корчицкий ${ }^{5}$; Роман Сергиенко 6 A \\ ${ }^{1}$ Corresponding author: д. экон. н., профессор, начальник центра, e-mail: tim68@ukr.net, ORCID: 0000-0001-5547-6303 \\ ${ }^{2}$ Соискатель степени магистр, e-mail: tim68@ukr.net
}


${ }^{3}$ Соискатель степени магистр, e-mail: tim68@ukr.net

${ }^{4}$ Соискатель степени магистр, e-mail: tim68@ukr.net

${ }^{5}$ Соискатель степени магистр, e-mail: tim68@ukr.net

${ }^{6}$ Соискатель степени магистр, e-mail: tim68@ukr.net

А Национальный университет обороны Украины имени Ивана Черняховского, пр-кт Воздухофлотский. 28 г. Киев, 03049, Украина

\begin{abstract}
Аннотация
Рассматривается опыт по организации системы государственных закупок вооружения и военной техники в США, Великобритания, Франция и ФРГ - государствах, которые имеют современную ведущую высокоразвитую оборонную промышленность и являются активными участниками мирового рынка вооружений. Предоставляемые общая характеристика системы закупок вооружений, особенности построения нормативноправовой базы по организации государственных закупок, парламентского $и$ общественного контроля за ними, способы определения поставщиков, устойчивые тенденции к упрощению и гибкости функционирования систем государственных закупок вооружений и меры по государственной поддержке производителей (поставщиков) товаров , работ, услуг. Ведущий иностранный опыт может быть полезен при сопоставлении основных его черт с новым Законом Украины “О оборонные закупки” от 17 июля 2020 года и продолжением усовершенствования функционирования отечественной системы закупок вооружений и гармонизации ее с лучшими мировыми практиками.
\end{abstract}

Ключевые слова: закупки, приобретение, программы, модели закупок, поставщики.

\title{
Analysis of international experience in organizing the system of armaments and military equipment public procurement
}

\author{
Ivan Tkach ${ }^{1}$ A; Vladimir Syniavskyi ${ }^{1}$ A; Eugene Yakovchuk ${ }^{1}{ }^{A}$; \\ Mikhail Rudy ${ }^{1}$ A; Vladimir Korchytsky ${ }^{1}$ A; Roman Sergienko ${ }^{1 \text { A }}$ \\ ${ }^{1}$ Corresponding author: Dr, Professor, Head of the Center, e-mail: tim68@ukr.net, ORCID: 0000-0001-5547-6303 \\ ${ }^{2}$ Applicant for a master's degree, e-mail: tim68@ukr.net \\ ${ }^{3}$ Applicant for a master's degree, e-mail: tim68@ukr.net \\ ${ }^{4}$ Applicant for a master's degree, e-mail: tim68@ukr.net \\ ${ }^{5}$ Applicant for a master's degree, e-mail: tim68@ukr.net \\ ${ }^{6}$ Applicant for a master's degree, e-mail: tim68@ukr.net \\ A National Defence University of Ukraine named after Ivan Cherniachovskyi, 28, Povitroflotsky, ave, Kyiv, 03049, Ukraine
}

\begin{abstract}
The experience of organizing the system of armaments and military equipment public procurement in the USA, Great Britain, France, Germany. These are states to have a modern leading highly developed defense industry and are active participants in the world arms market. The general characteristics of the arms procurement system, features of the legal framework construction for the organization of public procurement, parliamentary and public control over them, ways to identify suppliers, sustainable trends in simplification and flexibility of public procurement systems, and measures to support state producers (suppliers) of goods, works, services.
\end{abstract}

Keywords: purchases, acquisitions, programs, procurement models, suppliers.

\section{References}

1. On defense procurement: Law of Ukraine of 17.07.2020, № 808-IX.

2. On public procurement: Law of Ukraine, 25.12. 2015, № 922-VIII.

3. Strategy for the development of the defenseindustrial complex of Ukraine for the period up to 2028. Order of the Cabinet of Ministers of Ukraine dated June 20, 2018 № 442-r.

4. Gorbulin V.P., Shekhovtsov V.S., Shevtsov A.I. Problems of state regulation of prices for products of the defense-industrial complex of Ukraine. Strategic priorities. №2 (31). Kyiv, 
NISS, 2014.

5. Begma V.M. Normative-legal and institutional support of international military-economic cooperation of Ukraine. Strategic priorities. №4 (37). Kyiv, NISS, 2015.

6. Ivanova I.M. Features of the formation of the value of defense products. Strategic priorities. №2. Kyiv, NISS, 2016.

7. Methodical bases of system researches and the decision of problems of technical equipment of the armed forces of the state: monograph / Grib D.A. etc.; under the order of B.A. Demidova and O.P. Korosteleva. Kyiv: Stilos, 2016. 654 p., (639 p.)

8. Chepkov I.B., Zubarev V.V., Borokhvostov V.K. [etc.]., Theory of armaments. Scientific and technical problems and tasks. Kyiv: 2018.

9. Report on research work "Substantiation of recommendations for improving the efficiency of management of the procurement system of armaments and military equipment of the Ministry of Defense of Ukraine", code "Efficiency-C". Ivan Chernyakhovsky National University of Defense of Ukraine, 2020

10. DAU. 'Glossary of Defense Acquisition Acronyms and Terms'. Available from: https://www.dau.mil/glossary/Pages/Glossary .aspx\#!term|A|26772.

11. CJCSI 5123.01H August 31, 2018. Charter of the Joint Requirements Oversight Council (JROC) and Implementation of the Joint Capabilities Integration and Development System (JCIDS) Available from: https://www.jcs.mil/Portals/36/Documents /Library/Instructions/CJCSI\%205123.01H.pdf? ver=2018-10-26-163922-137.

12. DoDD 7045.14. January 25. 2013. Incorporating Change 1, August 29, 2017, The Planning, Programming, Budgeting, and Execution (PPBE) Available from: https://www.esd.whs.mil/Portals/54/Docume nts/DD/issuances/ dodd / 704514p.pdf? ver $=$ 2017-08-29-132032-353

13. DoDD 5000.01. May 12. 2003. Incorporating Change 2, August 31, 2018. URL: https://www.esd.whs.mil/Portals/54/Docume nts/DD/ issuances / dodd / 500001p.pdf

14. DoDI 5000.02. January 7, 2015 Incorporating Change 4, August 10, 2017 Available from:
https://www.esd.whs.mil/Portals/54/Docume nts/DD/issuances/dodi/500002_dodi_2015.pd $f$

15. Defense Logistics Agency. Available from: https://www.dla.mil/AtaGlance/.

16. Defense Advanced Research Projects Agency. Available from: https://www.darpa.mil.

17. Federal Acquisition Regulation. Available from: https://www.in.gov/indiana-ptac/files/FAR. pdf.

18. DFARS. Available from: https://www.acq.osd.mil/dpap/dars/dfarspgi/ current /

19. DFARS 213.3. Available from: http://www.acq.osd.mil/dpap/dars/dfarspgi/c urrent

20. DFARS 206.3. Available from: http://www.acq.osd.mil/dpap/dars/dfarspgi/c urrent

21. Small Business Innovation Research and Small Business Technology Transfer. Available from: https://www.sbir.gov/about

22. DIRECTIVE 2009/81 / EC OF THE EUROPEAN PARLIAMENT AND OF THE COUNCIL of 13 July 2009. Available from: https://eurlex.europa.eu/legalcontent/EN/TXT/?uri=celex\%3A32009L0081

23. Thresholds for Defense Directive 2009/81/EC. Available from: https://ec.europa.eu/growth/singlemarket/public-procurement/rulesimplementation/thresholds_en

24. The defense equipment plan 2018. Available from: https://www.gov.uk/government/ publications/the-defence-equipment-plan2018.

25. Defense Equipment and Support (DE\&S). Commons Briefing papers SN06903 (2014), House of Commons. Available from: https://researchbriefings.parliament.uk/Resea rchBriefing/Summary/SN06903

26. The Defense and Security Public Contracts Regulations 2011. Available from: http://www.legislation.gov.uk/uksi/2011/184 $8 /$ made

27. 2018 Procurement Thresholds. Available from: https://www.contracts.mod.uk/supplyingdefenceojeu-procurement-thresholds-2018/

28. The Single Source Contract (Amendment) (No. 
2) Regulations 2018. Available from: http://www.legislation.gov.uk/uksi/2018/135 $0 /$ made

29. An Overview: Single Source Procurement Framework: Ministry of Defense, June 2014. Available from: http://www.metasums.co.uk/uploads/asset_fi le/Overview\%20\%20-

\%20single\%20source\%20procurementof\%20F ramework.pdf

30. An introduction to defense procurement. Commons Library Briefing, 28 January 2019. Available from: https://researchbriefings.parliament.uk/Resea rchBriefing/Summary/CBP-8486\#fullreport

31. Bribery Act 2010 Available from: https://www.legislation.gov.uk/ukpga/2010/2 3/contents

32. Procurement at MOD. Available from: https://www.gov.uk/government/organisatio ns/ministry-of-defence/about/ procurement

33. Below Threshold Procurement under PCR 2015. MOD Commercial. An Essential Guide for Commercial Staff. September 2019. Available from:

https://www.aof.mod.uk/aofcontent/tactical/ toolkit/downloads/eupcr2015/eupcr2015_ below_threshold_guide.pdf

34. Low Value Requirements $<f 1 \mathrm{M}$. Available from:

https://www.aof.mod.uk/aofcontent/tactical/ toolkit/downloads/lovare/lovare_cps.pdf?zoo m_highlight $=\% 22$ procurement + of + low+value \%22\#search=\%22procurement\%20of\%20low $\%$ 20value\% 22

35. The Defense and Security Public Contracts (Amendment) (EU Exit) Regulations 2019. URL: http://www.legislation.gov.uk/ukdsi/ 2019/9780111176764

36. Public Command Code Available from: http://www.marche-public.fr/ccp/ccp-planreglementaire.htm.

37. France: Public Procurement 2019. Available from: https://iclg.com/practice-areas/publicprocurement-laws-and-regulations/france

38. The French White Paper on defense and national security URL: https://www.cfr.org/ content/publications/attachments/Dossier_de _presse_LBlanc_DSN_en_anglais.pdf
39. White Paper on Defense and National Security Available from: https://otan.delegfrance.org/ White-Paper-on-Defense-and-National-

Security

40. Presentation of the general direction of the armament Available from:

https://www.defense.gouv.fr/dga/ladga2/missions/presentation-de-la-directiongenerale-de-l-armement.

41. Ethan B. Kapstein. Smart Defense Acquisition: Learning from French Procurement Reform. Available from: https://www.files.ethz.ch/isn/110730/2009_1 2_CNAS\%20Policy\%20Brief\%20-

\%20defense\%20acquisition_1.pdf (access date: 05.10.2019).

42. Olena Salikhova Experience of France and Germany in creating conditions for raising the level of national high-tech industries. Economist. 2011. №11. Pp. 67-70. Available from: http://www.irbis-nbuv.gov.ua/cgibin/irbis_nbuv/cgiirbis_64.exe?C21COM=2\&12 $1 D B N=U J R N \& P 21 D B N=U J R N \& I M A G E \_F I L E \_D$ OWNLOAD=1\&Image_file_name=PD1.1019_1 9

43. Fundamentals of employment. Bundesamt for equipment, information technology and use of the Bundeswehr. Available from: https://www.baainbw.de.

44. Thomas Solbach. Public Procurement in Germany. Workshop on the Public Procurement Strategy. European Parliament. Brussels, February 19, 2018. Available from: http://www.europarl.europa.eu/cmsdata/138 604/06\%20-\%20SOLBACH\%20-

\%20Public\%20Procurement\%20in\%20German y.pdf

45. Germany: Public Procurement 2019. Available from: https://iclg.com/practice-areas/publicprocurement-laws-and-regulations/germany.

46. Fundamentals of employment. Bundesamt for equipment, information technology and use of the Bundeswehr. Available from: https://www.baainbw.de laccess date: 15.10.2019).

47. Thomas Solbach. Public Procurement in Germany. Workshop on the Public Procurement Strategy. European Parliament. Brussels, February`19, 2018. Available from: 
http://www.europarl.europa.eu/cmsdata/138 604/06\%20-\%20SOLBACH\%20-

\%20Public\%20Procurement\%20in\%20German y.pdf

48. Germany: Public Procurement 2019. Available from: https://iclg.com/practice-areas/publicprocurement-laws-and-regulations/germany.

49. Regierung beschließt Gesetz für schnellere Beschaffung Available from: https://www.bmvg.de/de/aktuelles/regierung -beschliesst-gesetz-fuer-schnellerebeschaffung- 144102

50. Kabinettsentwurf eines Gesetzes z beschleunigten Beschaffung im Bereich der Verideidigung und Sicherheit und Zur Optimierung der Vergabestatistik Available from: http://www.forum-vergabe.de/news- detail/kabinettsentwurf-eines-gesetches-zetarea-of-distribution-and-security-and-tooptimization-of-statistics-7961 /

51. Germany: Public Procurement 2019. Available from: https://iclg.com/practice-areas/publicprocurement-laws-and-regulations/germany.

52. Tkach I.M. Conceptual principles of military and economic security of the state: monograph. Kyiv: NUOU, 2018. 312 p. ISBN 978-617-7187-19-5

53. Parkhomenko, P., Lavruk, M., Tkach, I., \& Skurinevska, L. (2020). Problems pricing for defense products and solutions. Journal of Scientific Papers, Social Development and $\begin{array}{llll}\text { Security, } & 10 & \text { (3), 75-92. DOI: }\end{array}$ 10.33445/sds.2020.10.3.7 